Jurnal Teknologi Pendidikan, Vol. 9 No. 2 Oktober 2016, p-ISSN; 1979-6692, e-ISSN: 2407-7437

\title{
PENGARUH STRATEGI PEMBELAJARAN DAN KEMAMPUAN BERPIKIR LOGIS TERHADAP HASIL BELAJAR SEJARAH SISWA JURUSAN IPS SMA NEGERI 2 PEMATANGSIANTAR
}

\author{
Asnewastri ${ }^{1}$, R. Mursid ${ }^{2}$ \\ Pendidikan Sejarah Universitas Simalungun ${ }^{1}$, Pascasarjana Universitas Negeri Medan ${ }^{2}$ \\ asnewari_123@yahoo.com,mursid.tp@gmail.com ${ }^{2}$
}

\begin{abstract}
Abstrak: Penelitian ini bertujuan untuk mengetahui: (1) hasil belajar Sejarah siswa yang diajar dengan strategi pembelajaran elaborasi lebih tinggi dengan ekspositori, (2) hasil belajar Sejarah siswa yang memiliki kemampuan berpikir logis tinggi lebih tinggi dengan berpikir logis rendah dan (3) interaksi antara strategi pembelajaran dengan kemampuan berpikir logis dalam mempengaruhi hasil belajar Sejarah siswa. Metode penelitian yang digunakan adalah quasi eksperimen dengan desain faktorial $2 \times 2$. Teknik analisis yang digunakan adalah analisis varians dua jalur (Two Way Anava $2 \times 2$ ) dengan taraf signifikansi $\alpha=0,05$ dengan menggunakan Uji-F, pengujian uji lanjut menggunakan uji Scheffe. Temuan penelitian menunjukkan: (1) terdapat perbedaan yang signifikan antara hasil belajar Sejarah siswa yang diajar dengan strategi pembelajaran elaborasi dengan strategi ekspositori, (2) terdapat perbedaan yang signifikan antara hasil belajar Sejarah siswa yang memiliki kemampuan berpikir logis tinggi dengan berpikir logis rendah, dan (3) Interaksi antara strategi pembelajaran dan kemampuan berpikir logis akan memberikan efek yang tinggi dalam penguasaan materi pembelajaran sehingga hasil belajar Sejarah yang diperoleh tinggi.
\end{abstract}

Kata Kunci: strategi pembelajaran, kemampuan berpikir logis terhadap hasil belajar sejarah

Abstract: This study aims to determine: (1) the results of studying history students who are taught by learning strategy elaboration higher with expository, (2) the results of learning history students who have the ability to think logically high is higher by thinking logically low and (3) interaction between learning strategy and logical thinking skills in influencing student learning outcomes History. The method used is a quasi-experimental design with $2 \times 2$ factorial analysis technique used is the analysis of variance of two lanes (Two Way Anova $2 \times 2$ ) with significance level $\alpha=$ 0.05 using the Test-F, a further test testing use test Scheffe. The findings show: (1) there is a significant difference between the results of studying history students who are taught by learning strategies elaboration of the strategy expository, (2) there is a significant difference between the results of studying history students who have the ability to think logically high to think logically low, and (3) the interaction between the learning strategies and ability to think logically will give high effect in the mastery of learning material that learners' achievements obtained History high.

Keywords: learning strategies, the ability to think logically to the learning outcomes of history

\section{PENDAHULUAN}

Pembangunan pendidikan merupakan suatu hal yang sangat penting untuk diperhatikan. Melalui pembangunan sumber daya manusia (SDM) di bidang pendidikan merupakan modal utama dalam pembangunan bangsa. Untuk menghadapi persaingan dalam era globalisasi, pemerintah berusaha mengantisipasi melalui peningkatan kualitas sumber daya manusia dengan cara peningkatan kualitas pendidikan. Hal ini sesuai dengan Undang-Undang Nomor 20 Tahun 2003 tentang Sistem Pendidikan Nasional menyatakan bahwa: Pendidikan Nasional berfungsi mengembangkan kemampuan dan membentuk watak serta peradaban bangsa yang bermartabat dalam rangka mencerdaskan kehidupan bangsa, bertujuan untuk mengembangkan potensi peserta didik agar menjadi manusia yang beriman dan bertaqwa kepada Tuhan Yang Maha Esa, berakhlak mulia, sehat, berilmu, cakap, kreatif, mandiri dan menjadi warga negara yang demokratis dan bertanggung jawab.

Miarso (2007: 486) mengatakan bahwa "sumber daya manusia merupakan modal dasar 
pembangunan terpenting". Lebih lanjut dijelaskan pendidikan untuk pembangunan kualitas manusia meliputi segala aspek perkembangan manusia dalam harkatnya sebagai makhluk yang berakal budi, sebagai pribadi, sebagai masyarakat dan sebagai warga negara. Pendidikan harus mencerminkan proses memanusiakan manusia dalam arti mengaktualisasikan semua potensi yang dimilikinya menjadi kemampuan yang dapat dimanfaatkan dalam kehidupan sehari-hari di masyarakat luas. Selanjutnya Budiningsih (2005) mengemukakan bahwa sumber daya manusia ditentukan oleh karakteristik manusia dan masyarakat masa depan yang dikehendaki seperti kemandirian, tanggung jawab terhadap resiko dalam mengambil keputusan dan mengembangkan segala aspek potensinya.

Permasalahan ini dapat diminimalkan apabila guru sewaktu mengajar menggunakan strategi pengorganisasian pembelajaran yang tepat dan dapat membantu siswa dalam meningkatkan mutu dan keterampilannya. Menurut Purwanto (2007) dalam belajar di sekolah, faktor guru dan cara mengajarnya merupakan faktor yang sangat penting. Selanjutnya Sanjaya (2008) juga berpendapat bahwa guru adalah komponen yang sangat menentukan dalam implementasi suatu strategi pembelajaran. Artinya faktor guru juga berpengaruh dalam hal peningkatan hal belajar siswa. Peranan guru Sejarah SMA diharapkan mampu mengembangkan seluruh potensi yang ada dalam diri siswa. Pembelajaran Sejarah selama ini masih sangat jauh dari yang diharapkan, pengorganisasian materi selalu menggunakan kebiasaan-kebiasaan yang lama yaitu dengan menyampaikan materi pelajaran secara bertutur baik lisan (ceramah) ataupun diskusi tanpa menguraikan lebih mendalam materi yang dipelajari. Guru mengajar cenderung texk-book oriented dan belum menekankan pada proses berpikir siswa secara mandiri. Diskusi yang dibahas kadang tidak sesuai dengan konteks dan isu-isu yang sedang berkembang dalam masyarakat terutama yang berhubungan dengan materi pelajaran Sejarah.

Strategi pembelajaran elaborasi berhubungan dengan cara penyusunan pengajaran pada tingkat struktur isi pelajaran yakni berkenaan dengan cara memilih, menata, dan menujukkan interrelasi antara isi ajaran. Reigeluth (1983) sebagai pengembang teori elaborasi menyatakan bahwa apabila pengajaran diorganisasikan melalui strategi pembelajaran elaborasi maka akan menghasilkan belajar, sintesis dan retensi yang lebih baik sebagai hasil belajar.

Selain strategi pembelajaran yang digunakan oleh guru, hasil belajar siswa dipengaruhi oleh berbagai faktor, antara lain sebagaimana yang diungkapkan oleh Slameto (2003: 54) yaitu: (1) Ffaktor eksternal (faktor yang berasal dari luar diri siswa), (2) faktor internal (faktor yang berasal dari dalam diri siswa).

Bruce (1980) mengemukakan bahwa para pakar pembelajaran seperti Piaget (1970), Meril (1977) dan Romizowski (1981) menyebutkan bahwa karakteristik yang bersumber dari dalam diri siswa penting untuk diperhatikan dan sangat menentukan kualitas pembelajaran. Salah satu karakteristik siswa adalah kemampuan berpikir logis siswa tersebut, yang diprediksi akan menentukan keefektifan strategi pengorganisasian pembelajaran.

Belajar adalah suatu proses usaha yang dilakukan seseorang untuk memperoleh suatu perubahan tingkah laku yang baru secara keseluruhan, sebagai hasil pengalamannya sendiri dalam interaksi dengan lingkungannya (Slameto 2003: 2). Selanjutnya Skinner seperti dikutip Bigge (1982: 119) berpandangan bahwa belajar adalah proses adaptasi yang berlangsung secara progresif. Skinner percaya bahwa proses belajar akan optimal jika diberi penguatan (reinforcer). Skinner berpendapat bahwa proses belajar muncul akibat hubungan stimulus dan respon. Ketika seseorang belajar, maka responsnya menjadi lebih baik. Sebaliknya bila seseorang tidak belajar maka responsnya menurun (Dimyati, 2006: 9-10).

$$
\text { Secara sederhana Gagne }
$$

mendefinisikan belajar sebagai hasil dari interaksi antara individu dengan lingkungannya (Gagne \& Driscoll, 1989: 21). Gagne (dalam Bigge, 1982: 41) mendefinisikan belajar sebagai perubahan dalam prilaku dan keterampilan manusia yang dapat dipakai, dan bukan dianggap berasal dari proses pertumbuhan. Gagne memandang belajar sebagai proses perubahan prilaku akibat pengalaman yang dialaminya.

Chaplin seperti yang dikutip oleh Syah (2008: 65) memberikan batasan defenisi belajar yang menyinggung teori belajar Gagne dan Skinner. Chaplin membatasi belajar dengan dua rumusan yaitu: (1) belajar adalah perolehan perubahan tingkah laku yang relatif menetap 
sebagai akibat latihan dan pengalaman, (2) belajar ialah proses memperoleh respon-respon sebagai akibat adanya latihan khusus.

Hampir senada dengan Chaplin, Reber (dalam Syah, 2008: 66) membatasi belajar dengan dua definisi. Pertama, belajar adalah proses memperoleh pengetahuan. Istilah ini lebih sering dipakai dalam pembahasan psikologi kognitif. Kedua, belajar adalah suatu perubahan kemampuan bereaksi yang relatif langgeng sebagai hasil latihan yang diperkuat. Dalam definisi ini terkandung empat istilah yang penting dalam memahami makna belajar yaitu: (1) relatively permanent (yang secara umum menetap), (2) response potentiality (kemampuan bereaksi), (3) Reinforced (yang diperkuat) dan (4) Practice (latihan).

Biggs (dalam Syah, 2008: 67) mendefinisikan belajar dalam tiga rumusan, yaitu: Rumusan kuantitatif, rumusan institusional dan rumusan kualitatif. Secara kuantitatif belajar adalah kegiatan pengembangan kemampuan kognitif dengan fakta sebanyak-banyaknya. Dalam hal ini, belajar dipandang dari sudut seberapa banyak materi yang dikuasai siswa. Secara intitusional belajar dipandang sebagai proses validasi terhadap penguasaan siswa atas materi-materi yang telah dipelajari. Ukurannya adalah semakin baik mutu mengajar guru maka semakin baik pula mutu hasil belajar siswa. Sedangkan secara kualitatif belajar adalah proses memperoleh arti dan pemahaman serta cara menafsirkan dunia di sekeliling siswa. Belajar di sini difokuskan pada tercapainya daya fikir dan tindakan yang berkualitas untuk memecahkan masalah yang dihadapi siswa.

Dalam bahasa yang lebih sederhana Fajar (2004: 10) mendefinisikan belajar sebagai suatu proses perubahan dalam diri seseorang yang ditampakkan dalam bentuk peningkatan kualitas dan kuantitas tingkah laku seperti peningkatan pengetahuan, kecakapan, daya pikir, sikap, kebiasaan, dan lain-lain.

Hasil belajar didefinisikan oleh Romiszwoski (1981: 63) sebagai output (keluaran) dari suatu sistem pemrosesan input (masukan). Input dapat berupa berbagai informasi sedangkan output berupa performance (kinerja). Kinerja memberi petunjuk bahwa proses belajar telah terjadi. Romiszwoski mengkategorikan hasil belajar dalam dua macam yaitu keterampilan dan pengetahuan. Pengetahuan terdiri dari empat kategori yaitu: (1) pengetahuan tentang fakta,
(2) pengetahuan tentang konsep,

pengetahuan tentang prinsip dan (4) pengetahuan tentang prosedur. Fakta merupakan pengetahuan tentang objek yang nyata, yang merupakan asosiasi dari kenyataan dan informasi verbal dari suatu objek, peristiwa atau manusia. Konsep merupakan pengetahuan tentang tindakan demi tindakan yang bersifat linier dalam mencapai suatu tujuan, sedangkan prinsip adalah pernyataan mengenai hubungan dua konsep atau lebih, hubungan itu bersifat kausalitas, korelasi atau aksiomatis.

Gagne (Gagne \& Driscoll, 1989: 44) membagi hasil belajar dalam lima tipe yaitu: (1) informasi verbal, pengetahuan verbal ini disimpan sebagai jaringan proposisi-proposisi. Informasi verbal diperoleh dari kegiatan pembelajaran di sekolah, buku, radio, TV, percakapan orang lain dan lain-lain, (2) keterampilan intelektual, memungkinkan seseorang berinteraksi dengan lingkungannya melalui penggunaan simbol atau gagasan, (3) strategi kognitif, merupakan proses kontrol, yaitu proses internal yang digunakan siswa untuk memilih atau mengubah cara-cara memberikan perhatian, belajar, mengingat dan berfikir, (4) sikap merupakan pembawaan yang dapat dipelajari, dan dapat mempengaruhi prilaku seseorang terhadap lingkungannya dan (5) keterampilan motorik yaitu keterampilan yang tidak hanya mencakup kegiatan fisik, melainkan

Suparman (1997: 72) mengemukakan bahwa strategi pembelajaran berkenaan dengan strategi pengajaran dalam mengelola kegiatan pembelajaran untuk menyampaikan materi secara sistematik sehingga yang diharapkan dapat dikuasai pembelajar secara efektif dan efisien. Pembelajaran mengandung empat pengertian sebagai berikut: (1) Urutan kegiatan pembelajaran yaitu urutan kegiatan pengajar dalam menyampaikan isi pelajaran kepada pembelajar, (2) Metode pembelajaran yaitu cara pengajar mengorganisasikan materi pelajaran dan pembelajaran agar terjadi proses belajar secara efektif dan efisien, (3) Media pembelajaran yaitu peralatan dan bahan pembelajaran yang digunakan pengajar dan pembelajar dalam kegiatan pembelajaran dan (4) Waktu yang digunakan oleh pengajar dan pembelajar dalam menyelesaikan setiap langkah dalam kegiatan pembelajaran. Sedangkan Dick, W \& Carey, L (2005: 63) menjelaskan strategi pembelajaran sebagai satu set materi dan prosedur pembelajaran yang digunakan secara 
bersama-sama untuk mencapai hasil belajar siswa, yang memuat lima komponen utama yaitu: (1) aktivitas pembelajaran pendahuluan, (2) penyampaian informasi, (3) partisipasi peserta didik, (4) tes, (5) kegiatan lanjutan. Kedua defenisi yang dikemukan para ahli tersebut pada prinsipnya lebih menekankan pada aspek komponen dan prosedur pembelajaran.

David seperti yang dikutip Sanjaya (2008: 126) mendefinisikan strategi pembelajaran sebagai perencanaan yang berisi tentang rangkaian kegiatan yang didesain untuk mencapai tujuan pendidikan tertentu. Sedangkan menurut Kirby (1984: 5) strategi sesungguhnya, merupakan metode untuk menyelesaikan tugas-tugas, atau secara umum untuk mencapai tujuan. Strategi pembelajaran adalah metode untuk mencapai tujuan pembelajaran.

Prawiradilaga

(2008:

mendefinisikan strategi pembelajaran sebagai upaya yang dilakukan oleh perancang dalam menentukan teknik penyampaian pesan, penentuan metode dan media, alur isi pelajaran serta interaksi antara pengajar dan peserta didik. Strategi pembelajaran elaborasi merupakan aplikasi dari teori elaborasi. Dasar dari teori elaborasi berpijak pada psikologi kognitif yang lebih banyak memusatkan perhatian pada konsepsi bahwa perolehan dan retensi pengetahuan baru merupakan fungsi dari struktur kognitif yang sudah dimiliki sibelajar. Dua bidang kajian psikologi kognitif yang secara langsung mendukung kesahihan teori elaborasi adalah teori tentang struktur representasi kognitif dan proses ingatan

Strategi pembelajaran elaborasi berhubungan dengan cara penyusunan pengajaran pada tingkat struktur isi pelajaran yakni berkenaan dengan cara memilih, menata, dan menujukkan interrelasi antara isi ajaran. Reigeluth (1983) sebagai pengembang teori elaborasi menyatakan bahwa apabila pengajaran diorganisasikan melalui strategi pembelajaran elaborasi maka akan menghasilkan belajar, sintesis dan retensi yang lebih baik sebagai hasil belajar. Sebagai dukungan empirik mengenai strategi pembelajaran elaborasi masih sedikit kalangan yang mengenalnya. Namun demikian dukungan beberapa teori belajar yang bersumber pada psikologi kognitif yang pada akhirnya juga melahirkan model pembelajaran kognitif.
Dua kajian psikologi kognitif yang secara langsung mendukung kesahihan elaborasi yaitu struktur kognitif dan proses ingatan. Degeng (1989:128) menyatakan bahwa "struktur kognitif didefinisikan sebagai struktur organisasi yang ada dalam ingatan seseorang yang mengintegrasikan unsur-unsur pengetahuan yang terpisah-pisah kedalam suatu unit yang konseptual. Sedangkan proses ingatan menunjukkan bahwa pengolahan informasi dalam ingatan dimulai dari proses penyandian informasi (encoding), diikuti dengan penyimpanan informasi (storage) dan akhirnya menungkapkan kembali informasi yang telah disimpan dalam ingatan (retrieval)".

Menurut Degeng (1989) dalam pengembangan strategi pembelajaran elaborasi ada tujuh prinsip, yaitu: (1) penyajian kerangka isi, ialah menunjukkan bagian-bagian utama bidang studi dan hubungan utama diantara bagian-bagian yang lebih rinci, (2) elaborasi secara bertahap, prinsip kedua ini berkaitan dengan tahapan dalam melakukan elaborasi isi pengajaran. Elaborasi tahap pertama, akan mengelaborasi bagian-bagian yang tercakup dalam kerangka isi. Elobarasi tahap kedua akan mengelaborasi bagian-bagian yang tercakup dalam elaborasi tahap pertama, dan begitu seterusnya, sehingga urutan pengajaran bergerak dari umum-ke-rinci atau dari sederhana ke kompleks, (3) bagian terpenting disajikan pertama kali, prinsip yang ketiga berkaitan dengan pertanyaan, bagian mana dari semua bagian yang tercakup dalam kerangka isi atau dalam elaborasi tahap pertama, kedua, dan seterusnya, yang harus disajikan pertama kali.

Hamid (2007) berpendapat bahwa urutan pembelajaran dengan menggunakan elaborasi berpijak pada analogi "zoom lens" yaitu dimulai dengan pandangan yang menyeluruh yang menunjukkan bagian-bagian utama dan hubungannya, kemudian perhatian diarahkan kepada salah satu bagian utama untuk melihat sub bagian dan hubungannya antar sub bagian. Dengan demikian Degeng (1989) menyarankan langkah-langkah pengorganisasian pengajaran dengan menggunakan elaborasi sebagai berikut: (1) penyajian kerangka isi, dimana pengajaran dimulai dengan menyajikan kerangka isi yakni struktur yang memuat bagian-bagian yang paling penting dari bidang studi, (2) elaborasi tahap pertama. Elaborasi tahap pertama adalah mengelaborasi tiap-tiap bagian yang ada dalam kerangka isi, mulai dari bagian yang terpenting. 
Elaborasi tiap-tiap bagian diakhiri dengan rangkuman dan pensintesis yang hanya mencakup konstruk-konstruk yang baru saja diajarkan (pensintesis internal), (3) pemberian rangkuman dan sintesis eksternal. Pada akhir elaborasi tahap pertama, diberikan rangkuman dan diikuti pensintesis eksternal. Rangkuman berisi pengertian-pengertian singkat mengenai konstruk-konstruk yang diajarkan dalam elaborasi, dan pensistesis eksternal menunjukkan (a) hubungan-hubungan penting yang ada antar bagian yang telah dielaborasi, dan (b) hubungan antara bagian-bagian yang telah dielaborasi dengan kerangka isi. Pengorganisasian seterusnya adalah langkah ke (4) elaborasi tahap kedua. Setelah elaborasi tahap pertama berakhir dan diintegrasikan dengan kerangka isi, pengajaran diteruskan ke elaborasi tahap kedua, (5) pemberian rangkuman dan sintesis eksternal. Pada akhir elaborasi tahap kedua, diberikan rangkuman dan sintesis eksternal, seperti pada elaborasi tahap pertama, (6) setelah semua elaborasi tahap kedua disajikan, disintesiskan, dan diintegrasikan ke dalam kerangka isi, pola seperti ini akan berulang kembali untuk elaborasi tahap ketiga, dan seterusnya sesuai dengan ke dalam yang ditetapkan oleh tujuan pengajaran, (7) pada tahap akhir pengajaran disajikan kembali kerangka isi untuk mensintesiskan keseluruhan isi bidang studi yang telah diajarkan. Strategi ini dilakukan agar memudahkan proses pembuatan dan sekaligus pemahaman pensintesis.

Reigeluth (1983) menyarankan dalam pengorganisasian elaborasi sebaiknya dilakukan dengan memperhatikan langkah-langkah kegiatan sebagai berikut: (1) penyajian epitome, (2) elaborasi tahap pertama, (3) pemberian dan sintesis antar bagian, (4) elaborasi tahap kedua, (5) rangkuman dan sintesa akhir. Pada teori struktur kognitif Ausubel seperti yang dikutip Degeng (1989) menyatakan skemata yang dimiliki sesorang sangat berhubungan dengan perolehan dan retensi pengetahuan baru yang dipelajarinya. Selanjutnya pernyataan ini dikuatkan oleh Mayer yang dikutip Degeng (1989) bahwa skemata yang dimiliki siswa mempengaruhi kebermaknaan dan perolehan pengetahuan baru. Demikian pula Anderson yang dikutip Dahar (1989) menyatakan struktur kognitif sebagai faktor utama keberhasilan perolehan pengetahuan. Kesesuaian urutan elaborasi dengan proses urutan pembentukan ingatan, tidak saja akan meningkatkan ingatan, tetapi juga menjadikan belajar lebih efisien.

Strategi pembelajaran ekspositori sering dihubungkan dengan kurangnya latihan dalam pembelajaran, menggunakan buku secara monoton, kekakuan, penekanan pada pembelajaran berdasarkan fakta dan hafalan, menggunakan metode ceramah, dan lain-lain. Manson dan Williams menjelaskan seperti yang dikutip oleh Jarolimek \& Foster (1976: 95), pembelajaran yang berbasis pada siswa secara umum diajukan sebagai antitesis strategi pembelajaran ekspositori di mana pembelajar menjadi penerima pengetahuan. Strategi pembelajaran ekpositori lebih cocok digunakan untuk mentransfer pengetahuan.

Dalam strategi pembelajaran ekspositori ada beberapa prinsip yang harus diperhatikan, yaitu: (1) berorientasi pada tujuan, (2) prinsip komunikasi, (3) Prinsip kesiapan dan (4) prinsip berkelanjutan (Sanjaya, 2008: 179). Sanjaya (2009: 179) mengemukakan bahwa strategi pembelajaran ekspositori adalah strategi pembelajaran yang menekankan kepada proses penyampaian materi secara verbal dari seorang guru kepada sekelompok siswa dengan maksud agar siswa dapat menguasai materi pelajaran secara optimal.

Roy Killen dalam Sanjaya (2009) menamakan strategi pembelajaran ekspositori ini dengan istilah strategi pembelajaran langsung (direct instruction). Oleh karena strategi pembelajaran ekspositori lebih menekankan kepada proses bertutur, maka sering juga dinamakan istilah strategi "chalk and talk".

Dari pendapat diatas dapat disimpulkan bahwa berpikir adalah suatu gejala jiwa yang dapat meletakkan hubungan-hubungan pengetahuan yang telah diproleh seseorang baik berupa konsep, gagasan atau pengetahuan. Dalam berfikir selalu dipergunakan symbol yang dapat mewakili segala hal dalam pikiran. Dalam prosesnya, berpikir itu mempunyai tahapan-tahapan yang secara sistematis sebagai suatu rangkaian kesatuan antara awal berpikir sampai membuahkan hasil berpikir yang disebut pikiran. Menurut Suryabrata (2001) proses atau jalannya berpikir ada tiga langkah, yaitu: (1) pembentukan pengertian, (2) pembentukan pendapat, dan (3) penarikan kesimpulan.

Menurut Piaget dalam Panjaitan (2006: 27-29) kemampuan berpikir logis memiliki beberapa pengertian, antara lain: Skema, 
asimilasi, akomodasi dan ekuilibrium. Skema adalah struktur kognitif yang merupakan kemampuan berpikir individu untuk mengorganisasi lingkungannya. Secara sederhana skema dapat juga diartikan sebagai konsep yang dapat digunakan untuk mengidentifikasikan jenis-jenis rangsangan yang dating dari luar. Dengan demikian, seorang siswa jika telah memiliki kemampuan untuk mengidentifikasi dan mengklasifikasi jenis-jenis rangsangan yang dari luar, maka dia akan mampu untuk mempelajarai dan memikirkan cara-cara atau prosedur penyelesaian masalah atau soal-soal yang dihadapi secara sistematis.

Hipotesis penelitian ini adalah: (1) Hasil belajar Sejarah siswa yang diajar dengan strategi pembelajaran elaborasi lebih tinggi dibandingkan dengan hasil belajar siswa yang diajar dengan strategi pembelajaran ekspositori; (2) Hasil belajar Sejarah siswa yang memiliki kemampuan berpikir logis tinggi lebih tinggi dibandingkan dengan hasil belajar siswa yang memiliki kemampuan berpikir logis rendah; dan (3) Terdapat interaksi antara strategi pembelajaran dengan kemampuan berpikir logis dalam mempengaruhi hasil belajar Sejarah siswa.

\section{METODE}

Penelitian ini dilaksanakan di Sekolah Menengah Atas (SMA) Negeri 2 Pematangsiantar. Perlakuan atau treatment penelitian dilaksanakan dengan menyesuaikan jadwal mata pelajaran Sejarah. Populasi dalam penelitian ini adalah seluruh siswa kelas XI (dua belas) Jurusan Ilmu Pengetahuan Sosial (IPS) SMA Negeri 2 Pematangsiantar, terdiri dari 3 (tiga) kelas yaitu kelas $\mathrm{XI}_{\mathrm{IPS} 1}=40$ Orang,
$\mathrm{XI}_{\mathrm{IPS} 2}=40$ Orang, dan $\mathrm{XI}_{\mathrm{IPS} 3}=40$ orang dengan jumlah keseluruhan 120 orang. Dari keseluruhan populasi ditetapkan 2 (dua) kelas yang menjadi sampel. Masing-masing kelas memiliki karakteristik yang sama seperti penggunaan kurikulum, setiap kelas tidak memiliki siswa yang pernah tinggal kelas dan rata-rata memiliki umur yang tidak jauh berbeda. Sampel penelitian diperoleh dengan menggunakan cara cluster random sampling atau teknik pengambilan sampel secara acak. Dengan menggunakan teknik sampling di atas terpilih kelas $\mathrm{XI}_{\mathrm{IPS} 2}$ sebagai kelas eksperimen (kelas yang diberi perlakuan dengan strategi pembelajaran elaborasi) dengan jumlah 40 orang dan kelas $\mathrm{XI}_{\mathrm{IPS} 3}$ sebagai kelas kontrol (kelas yang diberi perlakuan dengan strategi ekspositori) dengan jumlah 40 orang.

Metode yang dipergunakan dalam penelitian ini adalah metode quasi eksperimen dengan desain penelitian faktorial $2 \times 2$. Melalui desain ini akan melibatkan dua kelompok sampel masing-masing ditetapkan sebagai kelompok eksperimen dengan menggunakan strategi pembelajaran elaborasi dan strategi pembelajaran ekspositori dalam pembelajaran Sejarah. Akhir dari eksperimen ini diharapkan mendapat informasi tentang perbedaan hasil belajar Sejarah melalui strategi pembelajaran elaborasi yang dibandingkan dengan strategi pembelajaran ekspositori. Strategi pembelajaran elaborasi dan strategi pembelajaran ekspositori sebagai variabel bebas sedangkan kemampuan berpikir logis dibagi menjadi kemampuan berpikir logis tinggi dan kemampuan berpikir logis rendah sebagai variabel moderator dan hasil belajar Sejarah sebagai variabel terikat. Berikut ditunjukkan variabel-variabel tersebut dalam Tabel 1.

Tabel 1. Rancangan Ekesperimen Desain Faktorial 2 x 2

Kemampuan
berpikir logis(B)


$\mathrm{A}_{2} \mathrm{~B}_{1}=$ Hasil belajar Sejarah yang diajar dengan strategi pembelajaran ekspositori dan memiliki kemampuan berpikir logis tinggi

$\mathrm{A}_{2} \mathrm{~B}_{2}=$ Hasil belajar Sejarah yang diajar dengan strategi pembelajaran ekspositori dan memiliki kemampuan berpikir logis rendah

Teknik analisis data yang digunakan adalah Teknik Statistik Deskriptif dan Inferensial. Teknik statistik deskriptif digunakan untuk mendeskripsikan data, antara lain: nilai rata-rata (mean), median, modus, standard deviasi dan kecenderungan data. Teknik statistik Inferensial digunakan untuk menguji hipotesis penelitian, di mana teknik Inferensial yang akan digunakan adalah teknik Analisis Varians (ANAVA) dua jalur (disain faktorial 2x2) dengan taraf signifikan $5 \%$. Sebelum ANAVA dua jalur dilakukan, terlebih dahulu dilakukan uji persyaratan analisis yakni uji persyaratan normalitas menggunakan Uji Lilliefors, sedangkan untuk uji persyaratan homogenitas menggunakan Uji $\mathrm{F}$ dan Uji Bartlett (Sudjana, 2005: 261).

Setelah melakukan pengujian persyaratan analisis, selanjutnya dilakukan pengujian Anava 2 jalur. Uji lanjut dilakukan dengan Uji Scheffe (n tidak sama).
Berdasarkan hipotesis penelitian yang telah dirumuskan di muka, maka berikut ini dapat disusun hipotesis statistik yang akan diuji sebagai berikut:

1. Hipotesis Pertama: Ho: $\mu_{\mathrm{A} 1}=\mu_{\mathrm{A} 2}$

Ha: $\mu_{\mathrm{A} 1}>\mu_{\mathrm{A} 2}$

2. Hipotesis Kedua: Ho $: \mu_{\mathrm{B} 1}=\mu_{\mathrm{B} 2}$

3. Hipotesis Ketiga: $\quad$ Ho : $\mathrm{A} \times \mathrm{B}=0$

$\mathrm{Ha}: \mathrm{A} \times \mathrm{B} \neq 0$

Keterangan:

$\mu_{A l}=$ Rata-rata hasil belajar Sejarah siswa yang diajarkan dengan strategi pembelajaran elaborasi.

$\mu_{A 2}=$ Rata-rata hasil belajar Sejarah siswa yang diajarkan dengan strategi pembelajaran ekspositori

$\mu_{B I}=$ Rata-rata hasil belajar Sejarah siswa yang memiliki kemampuan berpikir logis tinggi.

$\mu_{B 2}=$ Rata-rata hasil belajar Sejarah siswa yang memiliki kemampuan berpikir logis rendah.

$A \times B=$ Interaksi antara strategi pembelajaran dan kemampuan berpikir logis dalam mempengaruhi hasil belajar Sejarah siswa.

\section{HASIL DAN PEMBAHASAN \\ Hasil}

Tabel 2. Rangkuman Data Hasil Perhitungan Analisis Deskriptif.

\begin{tabular}{|c|c|c|c|c|}
\hline \multirow{2}{*}{\multicolumn{2}{|c|}{$\begin{array}{l}\text { RINGKASAN } \\
\text { DATA }\end{array}$}} & \multicolumn{2}{|c|}{ STRATEGI PEMBELAJARAN } & \multirow[b]{2}{*}{ JUMLAH } \\
\hline & & Elaborasi & Ekspositori & \\
\hline \multirow{2}{*}{$\begin{array}{l}\text { KEMAMPUAN } \\
\text { BERPIKIR } \\
\text { LOGIS }\end{array}$} & Tinggi & $\begin{array}{l}\mathrm{N}_{1}=18 \\
\Sigma \mathrm{X}=621 \\
\Sigma \mathrm{X}^{2}=21581 \\
\bar{X}_{1}=34.5 \\
\mathrm{SD}^{2}=6.55\end{array}$ & $\mid \begin{array}{l}N_{3}=19 \\
\Sigma X=498 \\
\Sigma X=13164 \\
\bar{X}_{3}=26.21 \\
S^{2}=3.96\end{array}$ & $\begin{array}{l}\mathrm{Nt}=37 \\
\Sigma X=1119 \\
\Sigma X^{2}=34745 \\
\bar{X}=30.36 \\
S^{2}=5.26\end{array}$ \\
\hline & Rendah & $\begin{array}{l}\mathrm{N}_{2}=22 \\
\Sigma X=651 \\
\Sigma X^{2}=19555 \\
\bar{X}=29.59 \\
\operatorname{SD}^{2}=7.9\end{array}$ & $\begin{array}{l}\mathrm{N}_{4}=21 \\
\Sigma \mathrm{X}=571 \\
\Sigma \mathrm{X}^{2}=15701 \\
\bar{X}=27.19 \\
\mathrm{SD}^{2}=5.81\end{array}$ & $\begin{array}{l}\mathrm{Nt}=43 \\
\Sigma \mathrm{X}=1222 \\
\Sigma \mathrm{X}^{2}=35256 \\
\bar{X}=28.39 \\
\mathrm{SD}^{2}=6.86\end{array}$ \\
\hline \multicolumn{2}{|c|}{ JUMLAH } & $\begin{array}{l}\mathrm{Nt}=40 \\
\Sigma \mathrm{X}=1272 \\
\Sigma \mathrm{X}^{2}=41136 \\
\bar{X}=32.05 \\
\mathrm{SD}^{2}=7.23\end{array}$ & $\mid$\begin{tabular}{|l}
$\mathrm{Nt}=40$ \\
$\Sigma \mathrm{X}=1069$ \\
$\Sigma \mathrm{X}^{2}=28865$ \\
$\bar{X}=26.7$ \\
$\mathrm{SD}^{2}=4.89$
\end{tabular} & $\begin{array}{l}\mathrm{Nt}=80 \\
\Sigma \mathrm{X}=2341 \\
\Sigma \mathrm{X}^{2}=70001 \\
\bar{X}=29.38 \\
\mathrm{SD}^{2}=6.06\end{array}$ \\
\hline
\end{tabular}


Untuk keperluan pengujian hipotesis dengan menggunakan teknik analisis varians dua jalur (ANAVA) faktorial $2 \times 2$ dan uji lanjut Scheffe diperlukan harga rata-rata tiap kelompok. Rangkuman data hasil belajar Sejarah dapat dilihat pada Tabel 2 dengan menggunakan analisis deskriptif. Setelah data Tabel 1 diolah dengan Anava 2 jalur faktorial 2x2, maka diperoleh hasil analisis seperti ditunjukkan pada Tabel 3 .

Tabel 3. Ringkasan Hasil Perhitungan ANAVA Faktorial 2x2

\begin{tabular}{|l|r|c|c|c|c|c|}
\hline Sumber varians & JK & Db & RJK & Fh & $\begin{array}{c}\text { Ft } \\
(\alpha=0.05)\end{array}$ & Ket \\
\hline Strategi Pembelajaran & 515.12 & 1 & 515.12 & 53.33 & & Signifikan \\
\cline { 1 - 5 } $\begin{array}{l}\text { Kemampuan berpikir } \\
\text { logis }\end{array}$ & 66.21 & 1 & 66.21 & 6.85 & & Signifikan \\
\hline Interaksi & 181.94 & 1 & 181.94 & 18.83 & \multirow{2}{*}{3.96} & Signifikan \\
\hline Antar Kelompok & 763.27 & & & & & \\
\cline { 1 - 4 } Dalam Kelompok & 734.22 & 76 & 9.66 & & & \\
\hline Total & 2260.76 & 79 & & & & \\
\hline
\end{tabular}

Keterangan:

$\mathrm{dk} \quad=$ Derajat kebebasan

$\mathrm{JK} \quad=$ Jumlah Kuadrat

RJK = Rata-rata Jumlah Kuadrat $(\mathrm{RJK}=$ $\mathrm{JK} / \mathrm{db}$ )

* $\quad=$ Uji F Signifikan (Signifikan pada $\alpha=$ $0,05)$.

Perbedaan Hasil Belajar Sejarah Siswa yang Diajar dengan Strategi Pembelajaran Elaborasi Lebih Tinggi dengan Siswa yang Diajar dengan Strategi Pembelajaran Ekspositori

$$
\begin{aligned}
& \text { Ho }: \mu_{\mathrm{A} 1}=\mu_{\mathrm{A} 2} \\
& \text { Ha }: \mu_{\mathrm{A} 1} \neq \mu_{\mathrm{A} 2}
\end{aligned}
$$

Kriteria pengujian: (1) Ha diterima dan Ho ditolak jika $F_{h}>F_{t}$ serta (2) Ha ditolak dan Ho diterima jika $F_{h}<F_{t}$.

Hasil perhitungan analisis varians tentang rata-rata hasil belajar Sejarah siswa yang diajar dengan strategi pembelajaran elaborasi sebesar $\bar{X}=31.80$ dan rata-rata hasil belajar siswa yang diajar dengan strategi pembelajaran ekspositori $\bar{X}=26.73$, didapat hasil perhitungan $F_{h}$ sebesar 53.33 dan harga $F_{t}$ untuk taraf signifikansi $\alpha=0.05$ dengan derajat kebebasan $\mathrm{d}_{\mathrm{k}(1: 76)}$ adalah 3.96. Didapat $F_{h}(53.33)>F_{t}(3.96)$, dengan demikian temuan penelitian menyimpulkan, bahwa Ho ditolak dan $\mathrm{Ha}$ diterima. Hipotesis penelitian yang menyatakan: Hasil belajar Sejarah siswa yang diajar dengan menggunakan strategi pembelajaran elaborasi lebih tinggi dibandingkan dengan siswa yang diajar dengan menggunakan strategi pembelajaran ekspositori pada taraf signifikansi $\alpha \square=0,05$ telah teruji kebenarannya.

Perbedaan Hasil Belajar Sejarah Siswa yang Memiliki Kemampuan berpikir logis Tinggi dengan Hasil Belajar Siswa yang Memiliki Kemampuan Berpikir logis rendah.

$$
\begin{aligned}
& \text { Ho }: \mu_{\mathrm{B} 1}=\mu_{\mathrm{B} 2} \\
& \text { Ha }: \mu_{\mathrm{B} 1} \neq \mu_{\mathrm{B} 2}
\end{aligned}
$$

Kriteria pengujian: (1) Ha diterima dan Ho ditolak jika $F_{h}>F_{t}$ serta (2) Ha ditolak dan Ho diterima jika $F_{h}<F_{t}$

Hasil perhitungan analisis varians tentang rata-rata hasil belajar Sejarah siswa yang memiliki kemampuan berpikir logis tinggi sebesar $\bar{X}=30.24$ dan rata-rata hasil belajar Sejarah siswa yang memiliki kemampuan berpikir logis rendah $\bar{X}=28.42$. didapat hasil perhitungan $F_{h}$ sebesar 6.85 dan harga $F_{t}$ untuk taraf signifikansi $\alpha=0.05$ dengan derajat kebebasan $\mathrm{d}_{\mathrm{k}(1: 76)}$ adalah 3,96. Didapat $F_{h}(6.85)>F_{t}(3.96)$, dengan demikian temuan penelitian menyimpulkan, bahwa Ho ditolak dan $\mathrm{Ha}$ diterima. Hipotesis penelitian yang menyatakan: Hasil belajar Sejarah siswa yang memiliki kemampuan berpikir logis tinggi lebih tinggi dibandingkan dengan siswa yang memiliki kemampuan berpikir logis rendah pada taraf signifikansi $\alpha=0,05$ telah teruji kebenarannya.

Terdapat Interaksi antara Strategi Pembelajaran dengan Kemampuan Berpikir logis dalam Mempengaruhi Hasil Belajar Sejarah Siswa.

Ho: $\mathrm{A} \times \mathrm{B}=0$

$\mathrm{Ha}: \mathrm{A} \times \mathrm{B} \neq 0$

Kriteria pengujian: (1) Ha diterima dan Ho ditolak jika $F_{h}>F_{t}$ serta (2) Ha ditolak dan Ho diterima jika $F_{h}<F_{t}$.

Hasil perhitungan analisis varians tentang rata-rata hasil belajar Sejarah siswa untuk setiap kelompok perlakuan adalah sebagai berikut: Rata-rata hasil belajar Sejarah 
siswa yang diajar dengan strategi pembelajaran elaborasi dan memiliki kemampuan berpikir logis tinggi $\bar{X}=34.5$ dan hasil belajar Sejarah siswa yang diajar dengan strategi pembelajaran elaborasi dan memiliki kemampuan berpikir logis rendah $\bar{X}=29.59$ sedangkan hasil belajar Sejarah siswa yang diajar dengan strategi pembelajaran ekspositori dan memiliki kemampuan berpikir logis tinggi $\bar{X}=26.21$ dan hasil belajar Sejarah siswa yang diajar dengan strategi pembelajaran ekspositori dan memiliki kemampuan berpikir logis rendah $\bar{X}=27.19$. Hasil perhitungan ANAVA faktorial $2 \times 2$ diperoleh hasil perhitungan $F_{h}=$
18.83 dan harga $F_{t}$ untuk taraf signifikansi $\alpha=$ 0.05 dengan $\mathrm{dk}=(1: 76)$ adalah 3,96. Didapat $\mathrm{F}_{\mathrm{h}}$ $(18.83)>F_{t}(3,96)$, dengan demikian temuan penelitian menyimpulkan, bahwa Ho ditolak dan Ha diterima. Hipotesis penelitian yang menyatakan: Terdapat interaksi antara strategi pembelajaran dengan kemampuan berpikir logis dalam mempengaruhi hasil belajar Sejarah siswa telah teruji kebenarannya pada taraf signifikansi 0.05. Interaksi antara strategi pembelajaran dengan kemampuan berpikir logis dalam mempengaruhi hasil belajar Sejarah siswa dapat divisualisasikan secara grafis pada gambar 1.

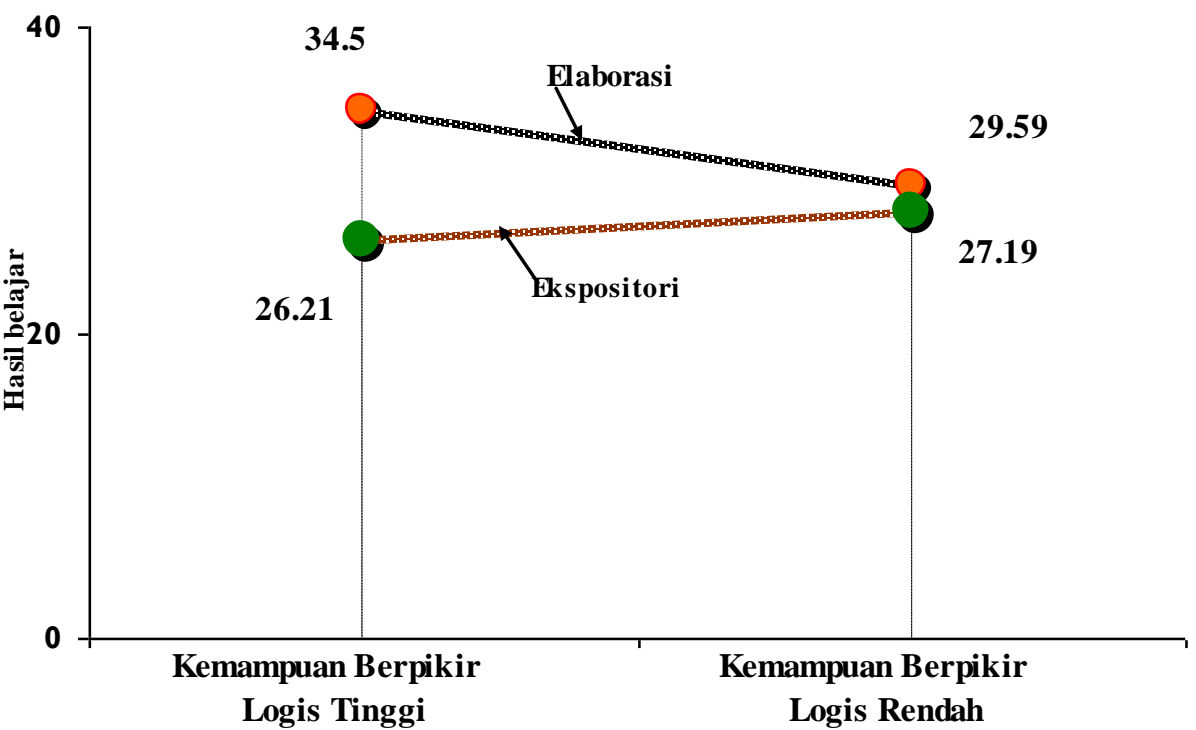

Gambar 1. Interaksi antara Strategi Pembelajaran dengan Kemampuan

Berpikir logis dalam Mempengaruhi Hasil Belajar Sejarah Siswa.

Berdasarkan hasil pengujian hipotesis ketiga yang menyatakan terdapat interaksi antara strategi pembelajaran dengan kemampuan berpikir logis dalam mempengaruhi hasil belajar Sejarah siswa, maka perlu dilakukan uji perbedaan rata rata antara dua proposisi untuk itu digunakan Uji Lanjut Scheffe. Gambar 1, menunjukkan terdapat interaksi antara strategi pembelajaran dengan kemampuan berpikir logis dalam mempengaruhi hasil belajar Sejarah siswa, akan tetapi strategi pembelajaran elaborasi lebih dominan dibandingkan dengan strategi pembelajaran ekspositori. Dengan kata lain semakin baik strategi pembelajaran yang digunakan oleh guru dalam menyampaikan bahan ajar, maka semakin tinggi pencapaian hasil belajar Sejarah siswa. Dilain pihak faktor kemampuan berpikir logis perlu diperhatikan karena terbukti bahwa kemampuan berpikir logis berpengaruh terhadap hasil belajar Sejarah siswa. Hasil pengujian dengan menggunakan Uji Scheffe dapat dilihat dalam Tabel 4.

Tabel 4. Ringkasan Hasil Pengujian dengan Menggunakan Uji Scheffe

\begin{tabular}{|c|c|c|c|}
\hline \multirow{2}{*}{ No } & \multirow{2}{*}{ Kelompok } & \multicolumn{2}{|c|}{ Uji Scheffe } \\
\cline { 3 - 4 } & A1 dengan A2 & Fh & $\mathrm{Ft}=0.05$ \\
\hline 1 & & $7.698^{*}$ & \\
\hline
\end{tabular}




\begin{tabular}{|c|c|c|c|}
\hline 2 & B1 dengan B2 & $2.835^{*}$ & \multirow{2}{*}{2.72} \\
\hline 3 & A1B1 dengan A2B1 & $8.080^{*}$ & $7.295^{*}$ \\
\hline 4 & A1B1 dengan A2B2 & $4.970^{*}$ & \\
\hline 5 & A1B1dengan A1B2 & $3.474^{*}$ & \\
\hline 6 & A1B2 dengan A2B1 & $2.532^{*}$ & \\
\hline 7 & A1B2 dengan A2B2 & 0.992 ts & \\
\hline 8 & A2B1 dengan A2B2 & Gun \\
\hline
\end{tabular}

Keterangan:

* : Signifikan.

ts : Tidak signifikan

A1 : Strategi pembelajaran elaborasi.

$\mathrm{A}_{2} \quad$ : Strategi pembelajaran ekspositori.

$\mathrm{B}_{1} \quad$ : Kemampuan berpikir logis tinggi.

$\mathrm{B}_{2} \quad$ : Kemampuan berpikir logis rendah.

$\mathrm{A}_{1} \mathrm{~B}_{1} \quad$ : Hasil belajar Sejarah siswa yang yang diajar dengan strategi

pembelajaran elaborasi dan memiliki kemampuan berpikir logis tinggi.

$\mathrm{A}_{1} \mathrm{~B}_{2} \quad$ : Hasil belajar Sejarah siswa yang diajar dengan strategi pembelajaran elaborasi dan memiliki kemampuan berpikir logis rendah.

$\mathrm{A}_{2} \mathrm{~B}_{1} \quad$ : Hasil belajar Sejarah siswa yang diajar dengan strategi pembelajaran ekspositori dan memiliki kemampuan berpikir logis tinggi.

$\mathrm{A}_{2} \mathrm{~B}_{2} \quad$ : Hasil belajar Sejarah siswa yang diajar dengan strategi pembelajaran

ekspositori dan memiliki kemampuan berpikir logis rendah.

\section{Pembahasan}

Hasil penelitian menunjukkan bahwa hasil belajar Sejarah siswa yang diajar dengan strategi pembelajaran elaborasi lebih tinggi dibandingkan dengan siswa yang diajar dengan strategi pembelajaran ekspositori, dimana nilai rata-rata hasil belajar Sejarah siswa yang diajar dengan strategi pembelajaran elaborasi lebih tinggi dibandingkan nilai rata-rata hasil belajar siswa yang diajar dengan strategi pembelajaran ekspositori. Hal ini juga ditunjukkan hasil perhitungan Uji Scheffe. Hal ini berindikasi bahwa strategi pembelajaran elaborasi lebih baik dalam meningkatkan pemahaman siswa tentang Sejarah dibandingkan dengan strategi pembelajaran ekspositori. Hasil ini menunjukkan bahwa untuk mengajarkan materi pelajaran Sejarah lebih baik menggunakan strategi pembelajaran elaborasi dibandingkan dengan strategi ekspositori.
Guru harus memotivasi, mendorong dan menstimulasi siswa sehingga tujuan belajar dapat terwujud, guru menilai dan mengatur situasi belajar sehingga tercapai tujuan pembelajaran. Untuk itu dibutuhkan strategi pembelajaran yang mampu untuk mendeskripsikan secara rinci, mendefenisikan dan memahami konsep-konsep serta struktur, memahami teori-teori dan mampu menganalisis serta mengevaluasi mata pelajaran Sejarah agar dapat mengasosiasikannya dalam pembelajaran yang efektif dan efisien. Penggunaan strategi pembelajaran elaborasi dalam Sejarah sangat tepat karena dalam proses pembelajaran yang dilakukan di mulai dari umum-ke-rinci dengan menguraikan lebih mendalam tergantung kedalaman materi serta diberikan sintesis dan rangkuman. Hal ini memungkinkan peserta didik dapat menguasai materi lebih mendalam karena bentuk penyajiannya yang selalu mengaitkan hubungan antara materi yang sedang dipelajari.

Hasil penelitian menunjukkan bahwa hasil belajar Sejarah siswa yang memiliki kemampuan berpikir logis tinggi lebih tinggi dibandingkan siswa yang memiliki kemampuan berpikir logis rendah, dimana nilai rata-rata hasil belajar Sejarah siswa yang memiliki kemampuan berpikir logis tinggi lebih tinggi dibandingkan siswa yang memiliki kemampuan berpikir logis rendah.

Hasil penelitian menunjukkan bahwa hasil belajar Sejarah siswa yang memiliki kemampuan berpikir logis tinggi lebih tinggi dibandingkan siswa yang memiliki kemampuan berpikir logis rendah jika diajar dengan strategi pembelajaran elaborasi dimana nilai rata-rata hasil belajar Sejarah siswa yang memiliki kemampuan berpikir logis tinggi lebih tinggi dibandingkan siswa yang memiliki kemampuan berpikir logis rendah jika diajar dengan strategi pembelajaran elaborasi. Tetapi sebaliknya nilai rata-rata hasil belajar Sejarah siswa yang memiliki kemampuan berpikir logis tinggi lebih rendah dibandingkan siswa yang memiliki kemampuan berpikir logis rendah jika diajar dengan strategi pembelajaran ekspositori. Hal ini berindikasi bahwa siswa yang memiliki 
kemampuan berpikir logis tinggi lebih mampu memahami secara mendalam terhadap tugas dan materi Sejarah diajar dengan strategi pembelajaran elaborasi.

Siswa yang memiliki kemampuan berpikir logis yang tinggi cenderung dapat menyelesaikan persoalannya sendiri tanpa mendapat hambatan yang berarti dan cenderung lebih memilih untuk belajar secara mandiri untuk memecahkan persoalannya sendiri. Siswa yang memiliki kemampuan berpikir logis rendah cenderung untuk menyukai cara belajar dan memecahkan persoalannya dengan bantuan orang lain. Siswa yang memiliki kemampuan berpikir logis rendah lebih menyukai cara belajar berkelompok untuk memecahkan persoalan secara bersama-sama.

Temuan penelitian menunjukkan bahwa terdapat interaksi antara strategi pembelajaran dengan kemampuan berpikir logis dalam mempengaruhi hasil belajar Sejarah siswa. Hasil belajar Sejarah siswa yang diajar dengan strategi pembelajaran elaborasi dan memiliki kemampuan berpikir logis tinggi lebih tinggi dibandingkan dengan siswa yang memiliki kemampuan berpikir logis rendah. Sedangkan hasil belajar Sejarah siswa yang diajar dengan strategi pembelajaran ekspositori dan memiliki kemampuan berpikir logis rendah lebih tinggi dibandingkan dengan siswa yang memiliki kemampuan berpikir logis tinggi. Hal ini memberikan pemahaman bahwa siswa yang memiliki kemampuan berpikir logis tinggi lebih baik diajar dengan strategi pembelajaran elaborasi sedangkan siswa yang memiliki kemampuan berpikir logis rendah lebih

Setiap guru dapat memfokuskan perhatian pada pengembangan materi Sejarah dengan kompetensi dasar. Guru dapat menyajikan materi pelajaran dengan cara menyampaikan kerangka isi dari kompetensi dasar, kemudian menguraikannya materi dalam kerangka isi yang merupakan tahapan elaborasi pertama. Kemudian dilanjutkan dengan pemberian rangkuman mengenai isi materi yang diajarkan dalam elaborasi tahap pertama dan melakukan sintesis eksternal dengan menjelaskan hubungan antar bagian yang telah diajarkan dan hubungannya dengan kerangka isi dari Sejarah. Selanjutnya diteruskan dengan tahap elaborasi kedua yaitu menguraikan lebih mendalam lagi salah satu materi yang telah dielaborasi pada tahap pertama, kemudian diberikan rangkuman dan sintesis. Demikian selanjutnya diteruskan dengan tahap elaborasi selanjutnya tergantung kedalam materi sesuai dengan yang diharapkan dalam tujuan pembelajaran.

Guru harus memotivasi, mendorong dan menstimulasi siswa sehingga tujuan belajar dapat terwujud, guru menilai dan mengatur situasi belajar sehingga tercapai tujuan pembelajaran. Untuk itu dibutuhkan strategi pembelajaran yang mampu untuk mendeskripsikan secara rinci, mendefenisikan dan memahami konsep-konsep serta struktur, memahami teori-teori dan mampu menganalisis serta mengevaluasi mata pelajaran Sejarah agar dapat mengasosiasikannya dalam pembelajaran yang efektif dan efisien. Penggunaan strategi pembelajaran elaborasi dalam mata pelajaran Sejarah sangat tepat karena dalam proses pembelajaran yang dilakukan di mulai dari umum-ke-rinci dengan menguraikan lebih mendalam tergantung kedalaman materi serta diberikan sintesis dan rangkuman. Hal ini memungkinkan peserta didik dapat menguasai materi lebih mendalam karena bentuk penyajiannya yang selalu mengaitkan hubungan antara materi yang sedang dipelajari.

Kemampuan berpikir logis dapat digunakan untuk mengidentifikasi dan mengklasifikasi rangsangan atau pengaruh berbeda dari luar sehingga siswa dapat dengan cepat dapat beradaptasi menyesuaikan apa yang diketahui dengan apa yang akan dipelajarinya. Kemampuan berpikir logis berpengaruh terhadap kemampuan siswa dalam menyelesaikan masalah atau soal-soal Sejarah. Didalam ranah kognitif, belajar Sejarah membutuhkan kemampuan berpikir logis tinggi guna menyelesaikan masalah-masalah dari gejala-gejala yang nyata hingga yang abstrak.

Berdasarkan penjelasan di atas, dapat disimpulkan bahwa terdapat keterkaitan pada proses pembelajaran secara keseluruhan yang dilakukan oleh seorang guru dalam pencapaian hasil belajar yang lebih tinggi. Strategi pembelajaran yang berbeda memberi pengaruh yang berbeda terhadap hasil belajar siswa dikaitkan dengan motivasi berprestasi yang dimilikinya.

Siswa yang memiliki kemampuan berpikir logis yang tinggi cenderung dapat menyelesaikan persoalannya sendiri tanpa mendapat hambatan yang berarti dan cenderung lebih memilih untuk belajar secara mandiri untuk memecahkan persoalannya sendiri sedangkan siswa yang memiliki kemampuan berpikir logis rendah cenderung untuk 
menyukai cara belajar dan memecahkan persoalannya dengan bantuan orang lain. Siswa yang memiliki kemampuan berpikir logis rendah lebih menyukai cara belajar berkelompok untuk memecahkan persoalan secara bersama-sama.

Siswa yang memiliki kamampuan berpikir logis tinggi apabila diberi perlakuan dengan strategi pembelajaran elaborasi akan memperoleh hasil belajar lebih tinggi dibandingkan dengan menggunakan strategi pembelajaran ekspositori, sebab siswa yang memiliki kamampuan berpikir logis tinggi mampu menemukan sendiri pengetahuan dan keterampilan yang dibutuhkannya dengan cara mengaitkan antara pengetahuan dan keterampilan dasar yang telah dimiliki dengan pengetahuan dan keterampilan baru yang dibutuhkannya. Siswa dengan kemampuan berpikir logis tinggi jika dibelajarkan dengan strategi pembelajaran elaborasi akan mampu berpikir secara logis dan rasional dalam menyelesaikan soal-soal secara rinci, terurut, dan menggunakan langkah-langkah penyelesaian soal secara sistematis, karena mampu mengaitkan antara materi yang sudah dikuasai dengan materi yang akan dipelajari olehnya.

Untuk siswa yang memiliki kemampuan berpikir logis rendah jika diajar dengan strategi pembelajaran ekspositori akan memperoleh hasil belajar Sejarah yang lebih tinggi dibandingkan jika diajar strategi pembelajaran elaborasi. Siswa dengan kemampuan berpikir logis rendah jika diajar dengan strategi pembelajaran elaborasi akan mengalami kesulitan untuk membangun atau mengkonstruk pengetahuan yang dibutuhkannya, sebab siswa dengan kemampuan berpikir logis rendah memiliki tingkat kecepatan yang rendah dalam menyelesaikan soal-soal Sejarah. Pembelajaran elaborasi menuntut kemampuan dalam menyelesajkan soal-soal secara rinci, terurut, dan sistematis

Berdasarkan penjelasan di atas, dapat disimpulkan bahwa terdapat keterkaitan pada proses pembelajaran secara keseluruhan yang dilakukan oleh seorang guru dalam pencapaian hasil belajar yang lebih tinggi. Strategi pembelajaran yang berbeda memberi pengaruh yang berbeda terhadap hasil belajar siswa dikaitkan dengan kemampuan berpikir logis yang dimilikinya. Temuan penelitian di atas mengindikasikan adanya interaksi antara strategi pembelajaran dengan kemampuan berpikir logis dalam mempengaruhi hasil belajar Sejarah siswa.

\section{PENUTUP}

Berdasarkan hasil pengujian hipotesis seperti yang telah diuraikan, penelitian ini menyimpulkan bahwa:

1. Hasil belajar Sejarah siswa yang diajar dengan strategi pembelajaran elaborasi lebih tinggi dibandingkan hasil belajar siswa yang diajar dengan strategi pembelajaran ekspositori.

2. Hasil belajar Sejarah siswa yang memiliki kemampuan berpikir logis tinggi lebih tinggi dibandingkan dengan siswa yang memiliki kemampuan berpikir logis rendah.

3. Terdapat interaksi antara strategi pembelajaran dengan kemampuan berpikir logis dalam mempengaruhi hasil belajar Sejarah siswa. Hasil belajar Sejarah siswa yang diajar dengan strategi pembelajaran elaborasi dan memiliki kemampuan berpikir logis tinggi lebih tinggi dibandingkan dengan siswa yang memiliki kemampuan berpikir logis rendah. Sedangkan hasil belajar Sejarah siswa yang diajar dengan strategi pembelajaran ekspositori dan memiliki kemampuan berpikir logis rendah lebih tinggi dibandingkan dengan siswa yang memiliki kemampuan berpikir logis tinggi. Dengan demikian, siswa yang memiliki kemampuan berpikir logis tinggi lebih baik diajar dengan strategi pembelajaran elaborasi sedangkan siswa yang memiliki kemampuan berpikir logis rendah lebih baik diajar dengan strategi pembelajaran ekspositori.

\section{DAFTAR PUSTAKA}

Ahmadi, Abu. (2003). Psikologi Umum. Jakarta: Rineka Cipta

Arikunto, Suharsimi. (2003). Dasar-dasar Evalusi Pendidikan (Ed. Revisi). Jakarta: Bumi Aksara

Budiningsih, C. Asri. (2005). Belajar dan Pembelajaran. Jakarta: Rineka Cipta

Buchari, Mochtar. 2001. Pendidikan Antisipatoris. Yogyakarta: Kanisius

Bigge, Morris L.(1982). Learning Theories For Teachers. New York: Harper \& Row

Caplin. (1999). Kamus Lengkap Psikologi. Jakarta: RajaGrafindo Persada 
Davies, Ivor K. (1981). Instructional Technique. New York: McGraw-Hill Book Company

Djaali \& Mulyono, P. (2008). Pengukuran dalam Bidang Pendidikan. Jakarta: Grasindo

Dick, W. \& Carey, L. (2005). The Systematic Design of Instructional. New York: Longman

Dimyati \& Mudjiono. (2006). Belajar dan Pembelajaran. Jakarta: Rineka Cipta

Driscoll, Marcy P. (1993). Psyichology of Learning for Instruction. Boston: Florida State University

Fajar, Arnie. 2004. Portofolio dalam pembelajaran IPS. Bandung: PT. Remaja Rosdakarya

Gagne, Robert M \& Driscoll, Marcy P. (1989). Essentials of Learnings for Instruction. New Jersey: Prentice Hall

Gerlach, Vernon S \& Ely, Donald P. 1980. Teaching \& Media, A Systematic Approach. New Jersey: Prentice Hall

Hamalik, Oemar. (2008). Perencanaan Pengajaran Berdasarkan Pendekatan Sistem. Jakarta: Bumi Aksara

Hamid, Abdul K. (2007). Teori Belajar dan Pembelajaran. Medan: Pasca Sarjana Unimed

Ihsan, H. Fuad. (2003). Dasar-dasar Kependidikan. Jakarta: Rineka Cipta

Jarolimek, John \& Foster, Clifford D. 1976. Teaching and Learning in the Elementary School. London: Macmillan

Kirby, John R. 1984. Cognitif Strategies and Educational Performance. London: Academic Press. inc

McCleland, David C. (1949). The Projective Expresion of Needs. American Psychological Association. Inc
Miarso, Yusufhadi. (2007). Menyemaih Benih Teknologi Pendidikan. Jakarta: Kecana

Nasution, S. (2006). Kurikulum dan Pengajaran. Jakarta: Bumi Aksara

Natawidjaja, Rochman. (1979). Psikologi Pendidikan. Jakarta: CV. Mutiara

Prawiradilaga, Dewi Salma. 2008. Prinsip Disain Pembelajaran. Jakarta: Kencana

Panjaitan, Binsar. (2006). Karakteristik Pembelajaran dan Kontribusinya Terhadap Hasil Belajar. Medan: Poda

Purwanto, N. M. (2007). Psikologi Pendidikan. Bandung: Remaja Rosdakarya

Ratumanan, Tanwey Gerson. (2002). Belajar dan Pembelajaran. Surabaya: Unesa

Reigeluth, C. M. (1983). Instructional Design Theories and Models: an Overview of their Current Status, Instructional Design: What is it? New Jersey: Publishers Hildshale

Romizwoski, A. J. (1981). Designing Instructional Systems, (Desicion Making in Course Planning and Curriculum Design). London: Kogan Page

Sanjaya, Wina. (2008). Strategi Pembelajaran. Jakarta: Kencana

Sanjaya, Wina. 2009. Strategi Pembelajaran Berorientasi Standar Proses Pendidikan. Jakarta: Kencana Prenada Media Group

Slameto. (2003). Belajar dan Faktor-faktor yang Mempengaruhinya. Jakarta: Rineka Cipta

Sudjana. (2005). Metoda Statistika. Bandung : Tarsito

Suparman, M. Atwi. (2001) Desain Instruksional. Jakarta: PAU-PPAI Universitas Terbuka

Suryabrata, S. (2004). Psikologi Pendidikan. Jakarta: RajaGrafindo Persada 